\title{
Piotr Teodorowski
}

\section{Migration dissensus among tweeters at \#BrexitDay}

\begin{abstract}
Liberal states simultaneously pursue policies of encouraging and controlling (un)desired immigration. Forces of representative democracy, nationhood, constitutionalism, and capitalism - each call for a distinct migration strategy. Previous research focusing on attitudes towards migration used quantitative methods examining values and perceptions that influence people's opinions. Still, it did not explore the diversity and complexity of sentiments. This paper aims to provide a more nuanced perspective based on tweets on and around the last day of the British membership in the European Union (31 January 2020). Data were collected using NCapture - a web-browser extension that downloaded tweets with hashtags \#Brexit, \#BrexitDay, and \#BrexitEve, and imported them directly to NVivo. Seven batches of tweets were captured on 30-31 January and 1, 7-10 February; extracting 250,095 published between 23 January and 10 February. All retweets, duplicates, non-English tweets, and spam were removed, leaving 888 tweets for the analysis. The dataset was coded twice, assigning sentiments towards Brexit as positive $(n=203)$, negative $(n=586)$, or neutral $(n=99)$, and using inductive thematic analysis. The findings showed the division of discourse on migration was more complicated than merely in favor and against immigration. Interestingly, they also exhibited the shift in the British debate from benefits and drawbacks of immigration to the reciprocity of migration policies in the future relations between the United Kingdom and the European Union.
\end{abstract}

Keywords: Brexit, migration, public opinion, Twitter, UK

JEL Classification Codes: F22, J6, O15, Z1, Z18

DOI: $10.33119 / \mathrm{KSzPP} / 2020.4 .5$

1 University of Liverpool, Institute of Population Health, Liverpool, United Kingdom, e-mail: p.teodorowski@liverpool.ac.uk, https://orcid.org/0000-0003-2172-8298 


\section{Spór migracyjny wśród użytkowników Twittera na \#BrexitDay}

\section{Streszczenie}

Państwa liberalne prowadzą politykę zachęcania do imigracji i jednocześnie kontrolowania jej. Demokracja reprezentatywna, państwo narodowe, konstytucjonalizm i kapitalizm - każdy z tych systemów wymaga konkretnej strategii migracyjnej. Poprzednie badania skupiały się na postawach wobec migracji, wykorzystywały metody ilościowe, których celem było analizowanie wartości i percepcji wpływających na opinie społeczeństwa. Stąd różnorodność i złożoność nastrojów społecznych jest mniej znana. Artykuł ma na celu przedstawienie perspektyw opartych na tweetach w ostatnim dniu (i okolicach) członkostwa Wielkiej Brytanii w Unii Europejskiej (31stycznia 2020 r.). Dane zebrano za pomocą NCapture - rozszerzenia przeglądarki internetowej, które pobierało tweety z hashtagami \#Brexit, \#BrexitDay i \#BrexitEve i importowało je bezpośrednio do NVivo. Siedmiokrotnie przechwycono tweety w dniach 30-31stycznia i 1, 7-10 lutego; zbierając 250095 tweetów opublikowanych między 23 stycznia a 10 lutego. Wszystkie retweety, duplikaty, tweety w jęz. innym niż angielski i spam zostały usunięte; pozostawiono 888 tweetów do analizy. Tweety zostały zakodowane dwukrotnie; stosunek do brexitu zakodowano jako pozytywny $(n=203)$, negatywny $(n=586)$ lub neutralny $(n=99)$. Przeprowadzono również analizę tematyczną. Wyniki pokazały, że podział dyskursu na temat migracji był bardziej skomplikowany niż tylko debata „za” i „przeciw” imigracji. Co ciekawe wyniki wskazują także na przesunięcie się granicy w brytyjskiej debacie migracyjnej od rozważania korzyści i wad imigracji po przyszłe, dwustronne zasady migracji między Wielką Brytanią a Unią Europejską.

Słowa kluczowe: brexit, migracja, opinia publiczna, Twitter, Zjednoczone Królestwo Kody klasyfikacji JEL: F22, J6, O15, Z1, Z18

\section{Introduction}

Over 250 million people are living in a different country than they were born (United Nations, 2017). States try to control migration, for example, through the visa system. Nowadays, globalization and technology made exercising this control even more challenging. Migration is no longer limited within geographically close countries or requires significant resources for people to relocate. Businesses that rely on a new workforce maintain pressure on states to accept immigrants. However, the host population often has mixed sentiments towards immigrants. In liberal states, voters' opinion matters as they choose their representatives, and many (not only populist) politicians appeal to those for whom migration is a concern. 
Most studies exploring attitudes towards immigration and migration policies used quantitative methods analyzing large survey data to capture sentiments towards immigration (McLaren, Johnson, 2007; Fitzgerald et al., 2011). This helped policymakers and researchers to notice values and perceptions that influence the host population's beliefs. However, at the same time, it did not explain the diversity and complexity of sentiments towards immigrants. This paper aims to provide a more nuanced perspective of individuals who expressed their views on a political event associated with restricting immigration. I set the scene through a brief literature review on why states simultaneously but paradoxically pursue both politics of openness and restrictions towards immigration. Later, I present the case study, the United Kingdom's withdrawal from the European Union. Former British Prime Minister Teresa May infamously used the slogan "Brexit means Brexit" to explain what the UK's leaving the European block involves. I intend to decipher how Twitter users imagine Brexit by exploring their perspectives on migration on and around the last day of the UK membership in the EU (31 January 2020). Secondly, I capture the participants' emotions and expectations towards the future reciprocal migration regime between the UK and the EU.

\section{Theoretical framework}

Liberal states simultaneously pursue politics of openness and closeness towards immigrants. Hampshire (2013) argued that this paradox is caused by forces of representative democracy, nationhood, constitutionalism, and capitalism - each urging states to have a different migration policy. Representative democracy and nationhood support limiting immigration as the public has identity and economic concerns. The government's actions to curb migration levels are limited by the rule of law (constitutionalism) exercised by human rights activists and organizations. The market economy continually requires new workers, and thus, governments feel obliged to allow more people in to sustain economic growth. While economists, political scientists, nationalism, and public opinion scholars explored states' policy towards migration, Hampshire offered an innovative way to bring these interdisciplinary explanations together. These could be underpinned by multiple theoretical perspectives, which are discussed below. States can have a "Janus face" towards immigrants (Hampshire, 2013) when governments have both inclusive and restrictive migration policies towards various migrants. For example, in the UK, EU citizens were allowed to move without restrictions and enjoy the same benefits as British nationals. In contrast, migrants from the rest of the world had to meet specific visa requirements to enter the country. 


\section{Restrictive influences}

Voters in representative democracies often have reservations towards migration. Thus, elected politicians and governments feel pressed to restrict migration levels. Local populations perceive newcomers as a threat to their identity, beliefs, and way of life, especially when migrants are from other cultures or religions (McLaren, Johnson, 2007). Racial prejudice (perceiving migrants as inferior) has been recognized as an independent effect in the negative attitudes towards newcomers (Gorodzeisky, Semyonov, 2015). Migration became a security issue (Bigo, 2002) as newcomers are seen as dangerous criminals (Fitzgerald et al., 2011) or even, in some cases, terrorists. However, research showed that immigration did not increase crime levels but sometimes even decreased them (Ousey, Kubrin, 2018).

Occasionally, local populations and migrants compete for the same resources, such as employment. Semyonov et al. (2006) showed that those with lower education and unemployed hold more anti-migration views. This supports arguments that during economic growth, the local population would perceive migrants more favorably than during a recession. Secondly, when migrants are perceived as a burden on public services such as the health system, education, and housing, the host population has negative sentiments towards them (Facchini, Mayda, 2009). The host population prefers to prioritize welfare access for other social groups such as older people, disabled or unemployed over migrants (van Oorschot, 2006).

Not all immigrants are perceived equally, as it might depend on the reason they moved to a new country. Those who migrated to improve their economic status might be perceived unfavorably as they had a choice to move. In contrast, involuntary migrants such as refugees or asylum seekers who left their home country because of war or persecution would be perceived more favorably as they "deserve" support (Yarris Castañeda, 2015). Negative sentiments could be towards specific groups. Hainmueller and Hangartner (2013) found that in Swiss naturalization referenda, the rejection rate differed based on the nationality of applicants.

Negative sentiments towards migrants could have single or multiple sources. Individuals' experiences with migrants also might impact their perspectives. The contact hypothesis (Allport, 1954) claims that when immigrants and the host population engage with one another, then they improve understanding and knowledge about each other. Otherwise, this understanding is based on stereotypes and generalizations. 


\section{Openness to migration}

The pressures to limit migration are counterbalanced in the state by two major groups of stakeholders: businesses and human rights activists. Western societies are aging and thus, have shortfalls in the workforce; businesses need to employ immigrants. Hampshire (2013) argued that developed economies rely on trade, manual, and highly educated workers. Relationships between states have become more interdependent (Keohane, Nye Jr, 1973), so businesses around the world are interlinked. Sharing new ideas and technology in the times of globalization is needed to keep the economy prospering, so bringing immigrants with new approaches and skills is key for many companies to stay in business (Hollifield, 2004).

The international legal documents such as the 1951 Geneva Convention relating to the Status of Refugees put new responsibilities on the signatory states to recognize the rights of refugees to move to another country. Further treaties restricting the power of states followed. The most progressive was the EU freedom of movement, which allowed each citizen of a Member State to settle in another to exercise the same rights and benefits as the citizens of the host country within the scope of application of the treaties. Many states developed their own domestic law granting rights to immigrants, for example, family reunification. Even if the state tries to curb migration, in liberal democracies these rights can be exercised in courts that prohibit summary deportations. Many (inter)national pro-migration organizations have been established, and those with human rights activists put pressure on the government to be more open. This supports the losing control argument that states' ability to restrict migration has become limited (Bhagwati, 2003).

\section{The United Kingdom and Brexit}

The UK has an ethnically and religiously multicultural population. A diverse community of migrants came from former British colonies such as India, Pakistan, and the Caribbean. More recent migration included the EU citizens who exercised their right to move freely within the EU as part of freedom of movement. Attitudes towards immigration among the British were mixed as some blamed migrants for employment competition, drawing salaries down, sending money to their home countries, and at least partial blame for the financial crisis (Harris et al., 2019). Supporters of migration could not build a positive economic case as the local population experienced negative consequences of the 2008 financial crisis (Balch, Balabanova, 2014). Negative views were at least supported (Spigelman, 2013) if not generated by the media as news coverage influenced public opinion (Blinder, Allen, 2016). While 
statistics showed that EU citizens in the UK paid more in taxes than took back (Oxford Economics, 2018), the British perceived them as a welfare burden. The UK population had the most substantial opposition to the free movement of people among all EU Member States (Vasilopoulou, Talving, 2019). After 2004 EU enlargement of ten new states, the UK unexpectedly experienced high-level migration from Eastern Europe. In response, politicians promised to cut down migration levels from hundreds to tens of thousands (Maidment, 2017). However, the scale of migration in the UK was often overestimated (Duffy, Frere-Smith, 2014). British society was divided as $44 \%$ supported reducing migration levels, and $39 \%$ believed that it should have remained the same (Blinder, Richards, 2020). This could also be associated with the Brexit divide as antimigration sentiments were associated more often with leave voters (Meleady et al., 2017). In 2016 the UK voted marginally to leave the EU. That referendum was seen as an anti-migrant vote as anti-migration messages were well-represented in the Leave campaign. Nigel Farage stood in front of the billboard showing a wave of asylum seekers (displaced during the refugee crisis and thus, not related to the EU's freedom of movement) with the caption "breaking point" (Wright, 2016) suggesting the British services and welfare cannot handle it anymore. However, the effect of the migration on voting patterns was mixed. Goodwin and Heath (2016) showed that more diverse communities voted more often to remain and only those with a sudden influx of EU citizens in the ten years before the referendum were more prone to support the leave.

After leaving the EU, the UK government supported the point-based system to reduce migration levels to the UK (Home Office, 2020). These proposals created tensions between supporters of reducing migration and those who are faced with an aging population, such as the Scottish government who suggested a Scottish visa (Scottish Government, 2020). The migration debate in the UK was ongoing with authoritative bodies such as the Migration Advisory Committee (2020), which suggested changes to the migration system. The opposition Labour Party supported keeping the freedom of movement during its annual conference. After the Brexit vote, the discussion about the freedom of movement temporarily shifted from migration levels to what the negative consequences of ending it would be for the UK (Morrison, 2019).

The potential change in the migration regime had a profound impact on individuals. EU citizens had a negative experience with Brexit. They reported the rise in prejudice towards them (Rzepnikowska, 2018) and feel more vulnerable even if they never experienced any prejudice themselves (Benedi Lahuerta, Iusmen, 2020). This had negative consequences on their mental health and well-being (Teodorowski et al., 2019). The UK leaving the EU also negatively disrupted the sense of belonging 
of both EU citizens in the UK (Teodorowski et al., 2019; Ranta, Nancheva, 2019; Zontini, Però, 2019) and the British in the EU (Higgins, 2019; Miller, 2019). The Withdrawal Agreement changed the legal position of the EU and the British nationals. EU citizens were required to apply for the settled status scheme. Grassroots organizations and activists raised concerns about the scheme, such as the lack of physical proof (The 3 Million, 2019) and that many EU residents in the UK would not meet the deadline because they would think they were ineligible to apply, vulnerable (e.g., victims of domestic abuse), struggle with the application (e.g., language barrier, digital literacy) and lack of up-to-date paperwork (Migration Observatory, 2018). British people raised concerns that they lost their freedom of movement to live and work around Europe as they might be allowed to reside only in the country which granted them the right to remain. The young generation might not have access to EU programs such as Erasmus+. Some hope that this could be secured by associate membership (Boffey, 2020).

The rise in anti-migrant movements in the West has been nothing new (Zamora-Kapoor, Verea, 2014), for example, the successes of Trump in the US, Le Front National in France, or Lega Nord in Italy. The UK experienced it through the growth of support for the United Kingdom Independence Party (UKIP) and later the Brexit Party. However, the Brexit referendum and its aftermath created a new political discourse around migration. Thus, this case is worth investigating in more detail. The UK going through Brexit is a novel case to explore as the polarization and societal division is high and as the results of the vote were marginal: $52 \%$ to leave and $48 \%$ to remain.

\section{Method}

Data from Twitter were recorded using NCapture - a web-browser extension that collects information from social platforms such as Twitter and imports it directly to NVivo (NVivo, 2020). There is no rule on how many tweets (a single post made on Twitter) can be captured at one time. This depends on Twitter's rules, traffic, privacy settings of the tweeters (authors of tweets). Only those published in the last seven days can be captured. I could not have recorded more than 18,000 tweets at once. Thus, this process was repeated in the mornings for seven days. While these were not all the tweets published online, they still provided a representative sample of the tweets for the analysis (Joseph et al., 2014).

To capture data around the last day of the United Kingdom's membership in the European Union, I used three hashtags (a tag which links a tweet to others with similar content) \#Brexit, \#BrexitDay, and \#BrexitEve. The \#Brexit was one of the most 
popular tags around the British withdrawal from the EU for the last couple of years. The other two became viral online around 30 January.

Seven batches of tweets were captured on 30, 31 January and 1, 7-10 February. These were published between 23 January and 10 February. Thus, it covered a week before and after the Brexit day (31 January). Overall, 250,095 tweets were extracted separately using three hashtags. Whilst NVivo merged datasets coming from the same hashtag (automatically removing any duplicates), if a tweet used more than one extracted hashtag, it could have appeared in more than one dataset. These were manually removed before the analysis. I used the "text search" tool with the same stem in NVivo to identify tweets related to migration. The search terms were: migrant OR migration OR immigrant OR emigrant OR refugee OR ethnic OR citizen OR (free AND movement) OR Polish OR Romanian. Polish and Romanian were included as they represented two of the largest European Union national groups based in the UK (Office for National Statistics, 2019) and were examples of stereotypical economic migration to the UK (Spigelman, 2013; Cheregi, 2018). In total, 4,619 tweets met these criteria. I removed all duplicates written in a language other than English, not related to the study aims and spam. This left 888 tweets for the analysis.

The analysis was supported by NVivo 11. The dataset was coded twice. Firstly, I assigned each tweet a sentiment towards Brexit. Secondly, using inductive thematic analysis (Braun, Clarke, 2006), codes were developed and then sorted into themes. The saturation in the analysis had been reached, and no new codes were appearing. Thus, I decided not to collect more data.

The convener of the School Ethics Review Panel at Robert Gordon University was approached about the study and confirmed that no ethical approval was required. The ethical issues on online platforms are still debated, so I decided to follow the framework for ethical research with social media data (Townsend, Wallace, 2016). When the tweeters used a hashtag, they wanted to reach as many people as possible, and NCapture extracted only public posts. However, as the topic was sensitive, some tweets appearing in this paper were paraphrased to protect the anonymity of the tweeters.

\section{Findings}

The analysis identified three themes and six subthemes. The emotional roller coaster focused on the emotional state and the profound feeling of change experienced by the tweeters. Make Great Britain Great Again explored what taking back control was supposed to imply and its unused potential in controlling migration. 
Lastly, Power of Uncertainty looked into what Brexit could mean to current and future migrants. Discussed topics were broad and covered the entire timeline of Brexit from announcing the 2016 referendum through the withdrawal agreement and its consequences to the future relationship. Some tweets included strong language, such as dark humor towards supporters of Brexit and prejudicial or racist comments (not only about EU citizens). Both sides of the debate used fake news. The authors of tweets were members of the public, media or journalists, academics, politicians, public and third sector organizations.

\section{Sentiments towards \#Brexit and \#BrexitDay}

All the tweets were coded as expressing positive ( $n=203)$, negative $(n=586)$, or neutral ( $\mathrm{n}=99$ ) sentiments towards Brexit and, consequently, the Brexit day itself. Positive sentiments were broad, and their support for it came from various angles, as represented by both supporters of the Brexit deal as well as those who wanted a clearcut break from the EU. Thus, they demanded a so-called hard Brexit.

"No more illegal migrants! [Home Secretary] Patel should resign! Since Brexit Day you welcomed all illegals and opened the entrance doors of UK! You make our blood boil!"

There were also some comments of support from other parts of the world congratulating the British on regaining "independence." Among these tweeters, there was a sense of celebration. Others were not particularly happy with Brexit but expected that in the long term, it would be worthwhile. Lastly, it included some non-EU migrants living in the UK who wanted to know from when it would be easier to get visas for their families. They perceived that the UK became more global and thus, open to non-EU migration because of Brexit.

Negative sentiments were shared, especially by those who were affected by Brexit as ethnic minorities (especially EU citizens in the UK) and British nationals losing their rights to move freely within Europe.

"I believe today is the last day my passport will have complete open legal rights to travel, work, study and easily immigrate to a country in the EU."

"Sad day \& end of an era the next generation won't be able to experience. \#EuropeanUnion \#Brexit \#UK \#Goodbye \#BrexitDay."

Others also criticized that this was a wrong decision, based on misleading facts, or argued that migration levels would not decrease because of Brexit, as more non-EU migrants will arrive. 
Neutral tweets were mostly informative about changes that happen post-Brexit, academic or policy analyses, and media coverage. There were also some tweets which expressed nonaligned opinions towards Brexit or asked for more information on how it might affect them.

"I have a question, I don't know much about \#brexit. So my question is what happens to the British citizens that had the privilege of owning property in other Europeans country, thanks to the EU relationship/agreement?"

Both positive and negative groups presented the same news to support their statement. One of the most popular was around the settled status, which supporters of Brexit called a fair scheme for EU citizens to register as there is a low rejection rate. In contrast, opponents of Brexit talked about those who might lose their rights.

"More than three million EU citizens apply to remain in the UK - with just six rejected." (Positive sentiment)

"Half million EU citizens in \#Brexit limbo" (this is an estimate of EU citizens who still had to register for the settled status) (Negative sentiment)

The majority of the tweeters had negative attitudes towards Brexit. This was not surprising as the anti-Brexit movement in the UK has been very active; for example, one million people joined an anti-Brexit march in London.

\section{Emotional roller coaster}

The tweeters often described their sentiments towards Brexit by expressing their emotions. The Brexit Day was a profound political change, and the tweeters' feelings were represented from one extreme to another. The process of leaving the EU took over three years, but 31 January became this symbolic, culmination moment to both Leavers and Remainers.

\section{Emotional state}

That Brexit Day caused an explosion of emotions from happiness to anger to sadness. A previous study exploring the mental health and well-being of EU citizens in the aftermath of Brexit compared their experience to stages of mourning: denial, sadness, and acceptance of the referendum result (Teodorowski et al., 2019). The tweeters' experiences were similar among Remainers, who expressed feelings of anger towards the results or abandonment by the UK government if they were British nationals living in Europe. 
"I am angry on behalf of all people (like me) with British nationality, or EU citizens living in \#UK over 20 years (or so) who are British affected by Brexit, and had no voting right."

Some hoped that Brexit would be reversed, but most of them felt heartbroken, sad, or even cried.

"I'm wearing black clothes today to mourn Brexit. It is not a day of celebration but one of deep sadness. I love you Europe, I love you my Polish partner, I am of Europe and Europe is part of me."

On the other hand, Leavers were excited that after three extensions, Brexit was eventually delivered. The whole discourse around Brexit was accompanied by emotions, but the anxiety was exceptionally high on the \#BrexitEve and \#BrexitDay among the tweeters.

\section{Metamorphosis and identity}

The delivery of the referendum result came with change. Everyone who had the nationality of an EU Member State was automatically an EU citizen. Like in Kafka's Metamorphosis, British nationals woke up one morning to find themselves inexplicably transformed, as they were no longer EU citizens. Some of them subsequently struggled to accept and adjust to this new role.

"I am no longer 'White British' or 'White English' I am now 'White European' or 'White Other' Write that up your ethnic monitoring."

Dual citizenship was perceived as a way to retain the privileges of being an EU citizen. However, this made the tweeters uneasy and emotional.

"Between \#Brexit and \#BecomingSwedish this week - it's been a bit of an emotional rollercoaster. (...) how it feels to remain an EU citizen, as my home country is about to leave the union."

Despite that, in legal terms, nothing changed for those who already were dual citizens. They felt their identity had transformed.

"United Kingdom, it's so weird to see you go. I was born in the Netherlands with an English passport. Always stayed as a dual citizen. British and Dutch in EU context. Now it feels so different. Will cherish the memories and remain loyal to both."

However, their feeling of belonging suffered as they assumed that they had to choose between two identities. 
"I'm an English born Irish citizen. I'm part of the community where I live, but after \#Brexit

I don't feel a sense of belonging here and my identity is as an EU citizen."

Those tweeters who were in the relationship between British and EU nationals were worried that there would be potential divisions within their families.

"Today is the last day I can walk freely through the EU citizens gate at the airport with my Irish wife and kids."

Because of the transitional period, all rights and benefits of being an EU citizen remained for the British. However, for the tweeters, the Brexit Day was this transformational moment when their metamorphosis took place.

\section{Make Great Britain Great Again}

Arguments supporting Brexit shared similarities with 2016 Trump's campaign slogan 'Make America Great Again', as many Brexiteers wanted the return to the past when, according to them, the UK was better off.

"Restoring Great Britain to her rightful place in the world."

Thus, leaving the EU was perceived as an opportunity for the UK to regain control over its governance and future.

\section{Taking back control}

Taking back control from Brussels was also one of the main slogans used by the Leave campaign. It summarized the argument that the UK had no control over what decisions were taken in the European Council as it had only $8 \%$ of the vote, $10 \%$ in the Parliament, gave up its right to veto in certain matters, and final legal judgments were taken in the European Court of Justice. These views were prevalent among the tweeters with sympathetic sentiments towards Brexit. They had the notion of micromanagement of British affairs by EU institutions and referred to regaining sovereignty over domestic issues.

"Today is Brexit Day! The benefits for the UK leaving the EU are numerous ranging from questionable immigration policies, concerns over Brussels micromanaging British affairs \& whether remaining in the EU is the best economic interests of the UK."

"Brexit is about the Sovereignty of British nationals." 
Interestingly, Brexit was not only supported by the far-right but also the far-left saw it as a means to achieve its long-term goals through regaining sovereignty.

"I'm heartbroken that we will lose free movement of people - but ending free movement of capital means we remove an obstacle to achieve socialism in our lifetime."

Both the left and right criticized the EU for not allowing them to control their own affairs. This showed that Leavers could have completely opposing views on what taking back control means.

\section{Less migration}

Some tweeters called for less migration to the UK. Their opinions were supported by various arguments, which occasionally included racial and prejudicial comments towards migrants. One group which was affected by migration felt immigrants were prioritized when accessing social housing, limited their access to the health system, and put wages down.

"Well once we get back control of our borders again. We can put a stop to net immigration of 250,000 people, every year! Maybe then us Brits can get a doctor's appointment \& we can take some strain off the NHS."

The second group claimed that limiting migration will reduce crime levels.

"In England we let immigrants come here. They kill children and we don't ship them back because of human rights."

There was a call for the new migration policies, which were supposed to encourage the desired type of migrants to move to the UK. This would support the argument that some people perceived EU citizens as undesired migrants who were lowskilled and abuse the social system.

"We will have an immigration policy that actually encourages genuine hardworking people to come to the UK."

Some tweeters argued that these new policies did not mean any deportation of current migrants. They also argued that Remainers were wrong by arguing that the settled status scheme was encouraging EU citizens to leave the UK.

"Remember all that complaining by Remainers about how bad the [settled] scheme was and how people were getting unfairly rejected? Well, only six people were refused on suitability grounds." 
Many perceived popular demand to limit migration as the main reason the Leave won the 2016 referendum. In the tweeters' comments, it remained as one of the key arguments. However, they also criticized the UK for being too Europe-focused and called for Britain to become a more global country. Secondly, they called for taking back control over one's destiny.

\section{Global Britain}

Some tweeters wanted the UK to become truly global as leaving the EU offered a new destiny for Britain. The focus on Europe was seen as limiting perspectives, and only the world offered new opportunities. These included more migration (a sort of new freedom of movement) between the UK and at least part of the Commonwealth, which is the political association of over fifty member states formerly part of the British Empire.

"Now that Brexit is done, can we focus on getting free movement between UK, NZ, AUS and CAN? \#CANZUK"

\#CANZUK became a hashtag referencing Canada, Australia, New Zealand, and the UK. This theme showed that the tweeters supporting Brexit did not share a vision on how to make Great Britain great again. To some, it was about reducing migration, and others argued for more migration from the Commonwealth; one group accused the $\mathrm{EU}$ of being too leftist and the other of being too right-wing.

\section{Power of uncertainty}

In contrast to the previous theme, here, the tweeters were unsure about how the post-Brexit world would look, especially the relationship between the UK and the EU. Interestingly, codes in this theme came mostly from those who opposed Brexit or Leavers who felt that their demands to limit migration were not delivered by the government through the Withdrawal Agreement. Thus, it left the consequences of Brexit open to unexpected surprises and unknown possibilities.

\section{Unmet promises lead to uncertain future}

The Brexit Day did not offer any clarification on what the future relationship between the UK and the EU would look like as it still had to be negotiated within the transitional period, which started with the moment when the UK officially left. To Brits, it meant difficulties in migrating to Europe. 
"This is what ending free movement into Britain means: barriers going up for Britons wanting to work in that enormous great market on our doorsteps."

"\#Brexit \& Johnson stripping British citizens of reciprocal free movement in Europe = bad news for Brits."

This change made some British tweeters feel like they were becoming second-class citizens and disadvantaged, in contrast with EU citizens who regained their right to live in the UK and move freely around Europe.

"Next Friday we become 2nd class citizens in our own continent. Every EU citizen has an advantage over you and your kids from next week."

Many tweeters felt that because of it, the referendum promises were not met. This group also includes those who expected more of a curb on migration levels. Those tweeters who supported the Tories in the last election and helped them to deliver a landslide victory were already dissatisfied with how things were handled.

"Honestly Tories only won [2019] election because of \#Brexit and immigration. They've let us down on that already."

However, there was still recognition that nothing actually changes as the UK still has to follow EU rules but will not have any decision-making powers to shape them.

"Daily life will continue as always: EU health card remains valid, no need for passports, pensions aren't affect, EU and British can travel, live and work across the continent."

This uncertainty around the future left many tweeters in the "limbo" and unsure what Brexit would mean to them. This was experienced especially by those who had already migrated or considered moving to another country. Growing concerns for this group led to emerging calls for solidarity and support for them.

\section{Solidarity and reassurance}

As the position of many EU citizens was unclear, some tweeters called for more support and reassurance, and in particular, they challenged the Leave campaign promise, which was supposed to protect the right to remain for all EU citizens based in the UK. The current prime minister was also one of the leaders of the Leave campaign.

"Boris Johnson, shame on you. You promised EU citizens living in the \#UK they could stay while in fact 116.000 children \& their families are refused a permanent stay. Your past \#Brexit campaign lies pile up. Your promises seem worthless. You can't be trusted." 
Arguments for EU migration included cultural and financial contributions. There were views that the UK could stop being a popular destination for skilled migrants.

"After Brexit, skilled migrants might be more selective in their decisions and choices to move where they would feel more welcome \& valued."

Because of raised hate crime levels towards ethnic minorities in the UK and how the government treated migrants, many tweeters felt ashamed of the actions of their fellow nationals. They would often call for donating a new 50 pence coin, which the UK government mined to celebrate Brexit, to charities supporting EU citizens or refugees.

"You can donate Brexit 50p coin in solidarity with refugees. Many charities build welcoming, inclusive and solidary [society]."

Solidarity and reassurance to EU citizens in the UK and British nationals were also visible in comments made by politicians who opposed Brexit in the UK (especially in Scotland) and European politicians who had a sizeable British minority, or their city had close ties with the UK.

"Thanks to Sutryk (Mayor of Wroclaw, Poland) and students for expressing their friendship with Oxford residents by showing the British flag in the market square."

EU citizens recognized and welcomed these messages.

"As an EU citizen who has settled in Glasgow, I say thank you Scotland."

Despite this solidarity and reassurance from some politicians, Brexit Day did not provide certainty around migration, leaving the tweeters with unmet promises, an uncertain future, and especially a lack of clarity around reciprocal migration.

\section{Discussion}

All arguments for and against migration were present among the tweeters, such as economic concerns, identity, and protection of human rights. These findings revealed that the views towards migration depended mostly on the priorities of individuals. When one perceived themselves as a migrant or potential migrant who could benefit from an open migration regime such as the EU freedom of movement, they were very open to it and thus opposed Brexit. Those who had to share their limited local resources with immigrants called for limiting migration. The issue of preserving one's identity was also relevant as some called for the end of freedom of movement 
with the EU but supported more migration from the Commonwealth. The Janus face towards immigrants could continue in the UK, as another group of immigrants would be prioritized. This could be explained by the perception of historical ties with these countries and that their nationals speak English. Nevertheless, they suggested this new special relationship should be with well-developed countries such as Canada or New Zealand. That idea fitted with the notion of "anglosphere" (Kenny, Pearce, 2016) that the UK's future is with other English speaking, protestant countries. Proponents of these ideas were not clear how these new regimes could reduce annual migration levels down to tens of thousands of people.

There were some misconceptions around the EU freedom of movement and how stopping it would reduce the overall migration to the UK. The tweeters often mixed their arguments around EU citizens, migration from the rest of the world, and refugees or asylum seekers. This showed that the concept of on what basis different groups came to the UK was confusing to some people. Freedom of movement did not encourage or allow illegal migration. British politicians failed to satisfy the expectations of British people despite that they had these opportunities within the liberal and legal system. For example, the British government could have limited movement for new EU Member States within the first years, as Germany did in 2004. Those who wanted to reduce migration levels might be disappointed with the future arrangements. However, some reconciliation between voters could happen. Hanel and Wolf (2019) demonstrated that Leave voters were more against immigrants, but the similarity of views between them and Remainers on migration was still $51 \%$. My findings added that some Leavers would support high migration levels from certain countries.

During the 2016 referendum, the Leave campaign succeeded in misrepresenting the freedom of movement and created a feeling of mass migration to the UK (Zappettini, 2019). Thus, one could have expected that migration would represent a significant part of online discussion. Whilst the extracted tweets did not cover all traffic on Twitter, the debate about migration was not so extensive. My initial data collection aimed to cover only three days around the Brexit day, but tweets focusing on migration were limited, so additional data collection took place within a week. This confirmed the findings of Ruzza and Pejovic (2019), who found that discussion on Facebook focused on the democratic legitimacy of the EU governance rather than the economy and migration.

This study had some limitations. As data came from Twitter, it was not representative of the general population. People more active digitally were well represented. NCapture did not record all tweets but only a sample, which, however, provided a good overview of views towards migration on Brexit Day. Secondly, findings 
covered opinions and experiences within a specific point in time. Future research should aim to overcome these challenges through a representative sample collected in a longitudinal study.

\section{Conclusion}

People's division on migration is more complicated than simply in favor and against immigration. The UK case showed that there are diverse views within Leave supporters on what Brexit was supposed to mean in terms of migration. These findings indicate that any new migration policy would not fully satisfy any side. Thus, future research should explore what influences people's support for a particular migration policy. The UK remains a good case study, but researchers should look at other countries (both with smaller and larger migrant populations). There is also a strong case for comparative studies.

Policymakers should consider the diversity of host populations' views and domestic pressures when deciding migration policies. Understanding local needs is important. More developed or aging regions of the country require a higher influx of migrants than others. In the UK, the Scottish Government called for more devolved powers so it could run a specific visa for Scotland. However, the UK government dismissed the proposal so far. This would not come as a surprise as both Remain and Leave campaigns in the 2016 referendum limited the scope of the debate to an "English-centered vision" of the future (Zappettini, 2019). There is a need to explore these possibilities further in both policy and academic research.

\section{Acknowledgments}

The author has conducted this study when based at the School of Nursing, Midwifery and Paramedic Practice, Robert Gordon University, Aberdeen, the United Kingdom. Currently, he is a PhD student at the University of Liverpool, the United Kingdom.

Piotr Teodorowski is supported by the National Institute for Health Research Applied Research Collaboration North West Coast (NIHR ARC NWC). The views expressed in this publication are those of the author(s) and not necessarily those of the National Institute for Health Research or the Department of Health and Social Care. 


\section{References}

Allport, G. (1954). The nature of prejudice. Cambridge: Mass, Addison-Wesley Pub.

Balch, A., Balabanova, E. (2014). Ethics, Politics and Migration: Public Debates on the Free Movement of Romanians and Bulgarians in the UK, 2006-2013. Politics, 36(1): 19-35.

Benedi Lahuerta, S., Iusmen, I. (2020). EU nationals' vulnerability in the context of Brexit: the case of Polish nationals. Journal of Ethnic and Migration Studies, 1-23.

Bhagwati, J. (2003). Borders Beyond Control. Foreign Affairs, January/February: 98-104.

Bigo, D. (2002). Security and Immigration: Toward a Critique of the Governmentality of Unease. Alternatives, 27(1): 63-92.

Blinder, S., Allen, W.L. (2016). Constructing Immigrants: Portrayals of Migrant Groups in British National Newspapers, 2010-2012. International Migration Review, 50(1): 3-40.

Blinder, S., Richards, L. (2020). UK Public Opinion toward Immigration: Overall Attitudes and Level of Concern. Retrieved from: https:/migrationobservatory.ox.ac.uk/wp-content/ uploads/2020/01/Briefing-UK-Public-Opinion-toward-Immigration-Overall-Attitudesand-Level-of-Concern.pdf (accessed: 18.02.2020).

Boffey, D. (2020). Sadiq Khan urges EU to offer Britons 'associate citizenship' [Online]. The Guardian. Retrieved from: https://www.theguardian.com/politics/2020/feb/18/sadiq-khanurges-eu-to-offer-britons-associate-citizenship (accessed: 19.02.2020).

Braun, V., Clarke, V. (2006). Using thematic analysis in psychology. Qualitative Research in Psychology, 3(2): 77-101.

Cheregi, B.-F. (2018). The Media Framing of Migration in Sending and Receiving Countries: The Case of Romanians Migrating to the UK. In: J. Mulholland, N. Montagna, E. SandersMcdonagh (Eds.), Gendering Nationalism: Intersections of Nation, Gender and Sexuality: 259-280. Cham: Springer International Publishing.

Duffy, B., Frere-Smith, T. (2014). Perceptions and Reality: 10 things we should know about attitudes to immigration in the UK. Ipsos MORI. Retrieved from: https://www.ipsos.com/ sites/default/files/migrations/en-uk/files/Assets/Docs/Publications/sri-perceptions-andreality-immigration-report-summary-2013.pdf (accessed: 18.02.2020).

Facchini, G., Mayda, A.M. (2009). Does the Welfare State Affect Individual Attitudes toward Immigrants? Evidence Across Countries. Review of Economics \& Statistics, 91(2): 295-314.

Fitzgerald, J., Curtis, K.A., Corliss, C.L. (2011). Anxious Publics: Worries About Crime and Immigration. Comparative Political Studies, 45(4): 477-506.

Goodwin, M.J., Heath, O. (2016). The 2016 Referendum, Brexit and the Left Behind: An Aggregate-level Analysis of the Result. The Political Quarterly, 87(3): 323-332.

Gorodzeisky, A., Semyonov, M. (2015). Not only Competitive Threat but also Racial Prejudice: Sources of Anti-Immigrant Attitudes in European Societies. International Journal of Public Opinion Research, 28(3): 331-354.

Hainmueller, J., Hangartner, D. (2013). Who Gets a Swiss Passport? A Natural Experiment in Immigrant Discrimination. American Political Science Review, 107(1): 159-187. 
Hampshire, J. (2013). The Politics of Immigration: Contradictions of the Liberal State. Cambridge: Polity Press.

Hanel, P.H.P., Wolf, L.J. (2019). Leavers and Remainers after the Brexit referendum: More united than divided after all? British Journal of Social Psychology, 59(2): 470-493.

Harris, C., Gawlewicz, A., Valentine, G. (2019). Attitudes towards immigration: responses to the increased presence of Polish migrants in the UK post 2004. Migration and Development, 1-20.

Higgins, K.W. (2019). National belonging post-referendum: Britons living in other EU Member States respond to "Brexit". Area, 51(2): 277-284.

Hollifield, J.F. (2004). The Emerging Migration State. International Migration Review, 38(3): 885-912.

Home Office (2020). The UK's points-based immigration system: policy statement, Retrieved from: https://www.gov.uk/government/publications/the-uks-points-based-immigrationsystem-policy-statement (accessed: 19.02.2020).

Joseph, K., Landwehr, P.M., Carley, K.M. (2014). Two 1\%s Don't Make a Whole: Comparing Simultaneous Samples from Twitter's Streaming API. In: W.G. Kennedy, N. Agarwal, S. Jay Yang (Eds.), Social Computing, Behavioral-Cultural Modeling and Prediction: 75-83. Cham: Springer International Publishing.

Kenny, M., Pearce, N. (2016). After Brexit: The Eurosceptic dream of an Anglosphere. Juncture, 22(4): 304-307.

Keohane, R.O., Nye JR, J.S. (1973). Power and interdependence. Survival, 15(4): 158-165.

Maidment, J. (2017). Theresa May commits Tories to cutting net migration to the UK to the tens of thousands. Retrieved from: https://www.telegraph.co.uk/news/2017/04/20/theresamay-commits-tories-cutting-net-migration-uk-tens-thousands/ (accessed: 19.02.2020).

Mclaren, L., Johnson, M. (2007). Resources, Group Conflict and Symbols: Explaining AntiImmigration Hostility in Britain. Political Studies, 55(4): 709-732.

Meleady, R., Seger, C.R., Vermue, M. (2017). Examining the role of positive and negative intergroup contact and anti-immigrant prejudice in Brexit. British Journal of Social Psychology, 56(4): 799-808.

Migration Advisory Committee (2020). Migration Advisory Committee (MAC) report: pointsbased system and salary thresholds. Retrieved from: https://www.gov.uk/government/ publications/migration-advisory-committee-mac-report-points-based-system-and-salarythresholds (accessed: 19.02.2020).

Migration Observatory (2018). Unsettled Status? Which EU Citizens are at Risk of Failing to Secure their Rights after Brexit? Retrieved from: https://migrationobservatory.ox.ac. $\mathrm{uk} /$ resources/reports/unsettled-status-which-eu-citizens-are-at-risk-of-failing-to-securetheir-rights-after-brexit/ (accessed: 20.02.2020).

Miller, R.G. (2019). (Un)settling home during the Brexit process. Population, Space and Place, 25(1): e2203.

Morrison, J. (2019). Re-framing free movement in the countdown to Brexit? Shifting UK press portrayals of EU migrants in the wake of the referendum. The British Journal of Politics and International Relations, 21(3): 594-611. 
Nvivo (2020). NCapture. Retrieved from: https://help-nv.qsrinternational.com/12/win/v12.1. 90-d3ea61/Content/ncapture/ncapture.htm (accessed: 17.02.2020).

Office For National Statistics (2019). Population of the UK by country of birth and nationality: July 2018 to June 2019. Retrieved from: https://www.ons.gov.uk/peoplepopulationandcommunity/populationandmigration/internationalmigration/bulletins/ukpopulationbycountryofbirthandnationality/july2018tojune2019 (accessed: 10.02.2020).

Ousey, G.C., Kubrin, C.E. (2018). Immigration and Crime: Assessing a Contentious Issue. Annual Review of Criminology, 1: 63-84.

Oxford Economics (2018). The Fiscal Impact of Immigration on the UK: A report for the Migration Advisory Committee. Retrieved from: https://www.oxfordeconomics.com/publication/ open/305055 (accessed: 24.02.2020).

Ranta, R., Nancheva, N. (2019). Unsettled: Brexit and European Union nationals' sense of belonging. Population, Space and Place, 25(1): e2199.

Ruzza, C., Pejovic, M. (2019). Populism at work: the language of the Brexiteers and the European Union. Critical Discourse Studies, 16(4): 432-448.

Rzepnikowska, A. (2018). Racism and xenophobia experienced by Polish migrants in the UK before and after Brexit vote. Journal of Ethnic and Migration Studies, 45(1): 1-17.

Scottish Government (2020). Plan for Scottish Visa. Retrieved from: https://www.gov.scot/ news/plan-for-scottish-visa/ (accessed: 18.02.2020).

Semyonov, M., Raijman, R., Gorodzeisky, A. (2006). The Rise of Anti-foreigner Sentiment in European Societies, 1988-2000. American Sociological Review, 71(3): 426-449.

Spigelman, A. (2013). The depiction of Polish migrants in the United Kingdom by the British press after Poland's accession to the European Union. International Journal of Sociology and Social Policy, 33 (1/2): 98-113.

Teodorowski, P., Woods, R., Czarnecka, M., Kennedy, C. (2019). How Brexit impacts EU citizens' mental health and wellbeing: research findings. Retrieved from: https://rgu-repository. worktribe.com/output/845732/how-brexit-impacts-eu-citizens-mental-health-and-wellbeing-research-findings (accessed: 11.11.2020).

The 3 Million (2019). Physical Proof. Retrieved from: https://www.the ${ }^{3}$ million.org.uk/physicalproof (accessed: 25.09.2019).

Townsend, L., Wallace, C. (2016). Social media research: A guide to ethics. Retrieved from: https://www.gla.ac.uk/media/Media_487729_smxx.pdf (accessed: 21.02.2020).

United Nations (2017). Population facts. Retrieved from: https://www.un.org/en/development/ desa/population/publications/pdf/popfacts/PopFacts_2017-5.pdf (accessed: 11.11.2020).

Van Oorschot, W. (2006). Making the difference in social Europe: deservingness perceptions among citizens of European welfare states. Journal of European Social Policy, 16(1): 23-42.

Vasilopoulou, S., Talving, L. (2019). Opportunity or threat? Public attitudes towards EU freedom of movement. Journal of European Public Policy, 26(6): 805-823.

Wright, O. (2016). EU referendum: Nigel Farage’s anti-migrant poster like 1930s fascist propaganda, says George Osborne. The Independent. Retrieved from: https://www.independent. co.uk/news/uk/politics/eu-referendum-poster-nigel-farage-polls-michael-gove-a7089946. html (accessed: 17.02.2020). 
Yarris, K., Castañeda, H. (2015). Special Issue Discourses of Displacement and Deservingness: Interrogating Distinctions between "Economic" and "Forced" Migration. International Migration, 53(3): 64-69.

Zamora-Kapoor, A., Verea, M. (2014). Public attitudes toward immigration in turbulent times. Migration Studies, 2(2): 131-134.

Zappettini, F. (2019). The Brexit referendum: how trade and immigration in the discourses of the official campaigns have legitimised a toxic (inter) national logic. Critical Discourse Studies, 16(4): 403-419.

Zontini, E., Però, D. (2019). EU Children in Brexit Britain: Re-Negotiating Belonging in Nationalist Times. International Migration, 58(1): 90-104. 